\title{
En bloc resection and prosthesis implantation to treat malignant fibrous histiocytoma of the humerus
}

\author{
Jun Sun ${ }^{D}$, Ru-Ming Zhang ${ }^{B}$, Yu-Xin Zheng ${ }^{A, F}$ \\ Department of Orthopedics, Shuguang Hospital affiliated to Shanghai University of Traditional Chinese Medicine, Shanghai, China \\ A - research concept and design; B - collection and/or assembly of data; C - data analysis and interpretation; \\ $D$ - writing the article; $E$ - critical revision of the article; $F$ - final approval of article
}

\section{Yu-Xin Zheng \\ E-mail: prozrm1@126.com \\ Funding sources \\ None declared \\ Conflict of interest \\ None declared}

Address for correspondence

Received on May 17, 2015

Revised on August 26, 2015

Accepted on June 17, 2016

\section{Abstract}

Background. Malignant fibrous histiocytoma (MFH) of the bone is a rare tumor. Most studies comparing limb salvage and amputation have reported that limb salvage had no adverse effect on the long-term survival of patients. This study evaluates the oncological outcomes of limb salvage procedures that were used for 15 patients with MFH of the humerus.

Objectives. The aim of this study was to assess the functional and oncological outcomes of patients with malignant fibrous histiocytoma of the humerus after en bloc resection and prosthesis implantation.

Material and methods. A retrospective review of the charts of 15 patients who had undergone resection of malignant fibrous histiocytoma of the humerus followed by reconstruction with prosthesis was used in this study. A functional evaluation was based on Enneking's modified system of the functional evaluation of surgical management for musculoskeletal tumors. Complications of the procedures were also analyzed.

Results. Eight men and 7 women at an average age of 52.9 years were included in the study. The tumor involved the distal humerus in 3 patients, the proximal humerus in 8 patients and the mid-shaft humerus in 4 patients. Excellent results were achieved in 4 patients, good to fair in 10 and poor in 1 . One patient had local recurrence. Pulmonary metastases occurred in 6 patients.

Conclusions. Limb salvage surgery with chemotherapy is a viable treatment option for patients with malignant fibrous histiocytoma of the humerus.

Key words: malignant fibrous histiocytoma, limb salvage, prosthesis implantation

DOI

10.17219/acem/63744

\section{Copyright}

Copyright by Author(s)

This is an article distributed under the terms of the

Creative Commons Attribution Non-Commercial License

(http://creativecommons.org/licenses/by-nc-nd/4.0/) 
Malignant fibrous histiocytoma (MFH) is a pleomorphic tumor which is made up of fibroblasts, myofibroblasts and histiocytes. In adults, it is the most common soft tissue tumor. But osseous MFH is an unusual tumor, accounting for less than $2 \%$ of all primary malignant osseous tumors. ${ }^{1,2}$ Primary osseous MFH is a central disorder detected in the osseous diaphysis or metaphysis that results in invasive bone damage and a soft tissue mass. The main characteristic of osseous MFH is the high local recurrence metastasis. It is recommended to treat MFH with a combination of surgical interference and neoadjuvant chemotherapy. ${ }^{2}$ As the principal goal is prolonging survival, osseous MFH that needs surgical removal can be treated by either limb salvage or amputation. Most of the studies have reported that limb salvage had no bad influence on the long-term survival rate of the patients when comparing amputation and limb salvage. ${ }^{2}$ This study assessed the efficacy of the limb salvage procedures that were applied for 15 patients with MFH of the humerus.

\section{Material and methods}

This study included 15 patients ( 8 men and 7 women) with a mean age of 52.9 years (range $30-71$ years). Assessments were made using local X-ray, magnetic resonance imaging (MRI), chest CT scanning and technetium bone imaging. Tumor staging was carried out according to the Enneking system. ${ }^{3}$ The distal humerus was affected in 3 patients, the proximal humerus in 8 patients and the midshaft humerus in 4 patients.

All patients before surgery had chemotherapy with 4 cycles of cisplatin and doxorubicin. Then the operation was performed. During the operation, in addition to en bloc of the humerus, an extended wide margin resection was achieved in all patients. The level of bone dissection was determined by examining the roentgenograms, technetium bone scanning, computed tomograms and MRI. The lesion was removed as widely or radically as possible. The margin was at least $7 \mathrm{~cm}$ above or below the limit of increased activity of the bone scan. Besides the tumor resection, subfascial dissection with the removal of all of the muscles in the compartment was done. At the level of the bone osteotomy, the muscles were severed. Custom-made prosthesis implantation was done to reconstruct the resected defect. After the operation, all the patients received chemotherapy of doxorubicin and cisplatin for 3-6 cycles. In this study, no patients accepted radiotherapy before or after surgery.

The functional outcome criteria were assessed with the 30-point Enneking scoring system, with 5 representing full function and 0 representing complete disability for each of 6 criteria. ${ }^{4}$ All of the quantitative data was assessed using a questionnaire confirmed to possess low intra-observer variability (Table 1$)$. The quantitative score was divided into normal (30 points), excellent (24-29 points), good (19-23 points), fair (12-18 points) and poor (less than 11 points). An assessment of function was done for each patient 6 months after the operation. All of the patients needed to return for follow-up to inspect metastasis, recurrence, or implanted-related complications monthly for the first 6 months, then quarterly after that for the next 3 years. The follow-up study was terminated if the patient died.

\section{Result}

The average follow-up period was 28 months (range 6-56 months). At the 6-month follow-up, 4 of the 8 proximal humerus patients had attained excellent functional outcomes. Three distal humerus, 4 of the 8 proximal humerus and 3 of the 4 mid-shaft humerus were good to fair. One mid-shaft humerus was poor.

One patient had local recurrence at 14 months. An amputation was done, but the patient ultimately died of metastatic disease at 20 months following the premier limb salvage procedure. Metastatic tumors of the lung occurred in 6 patients without local recurrence; 2 underwent pulmonary metastasis resection, but all ultimately died of metastatic disease. Table 2 shows patient characteristics and outcomes.

\section{Illustrative case (patient no. 7)}

A 56-year-old female presented with a mass in her right upper arm with serious pain. She had been previously diagnosed with soft tissue MFH (storiform-pleomorphic or undifferentiated pleomorphic sarcoma) of her left medial thigh. She had 3 operations to remove the primary and recurrent sarcoma, including the removal and reconstruction of the anterior compartment of the thigh.

The right arm was in the adduction and internal rotation position in the physical examination. The diameter of the upper arm increased from the middle part of the upper arm to the elbow. Abnormal movement and tenderness were also found at the distal $1 / 3$ of the upper arm. The major function of the shoulder and elbow joints was lost. The length of the right upper arm decreased by $1.5 \mathrm{~cm}$ compared to the opposite side. However, the function of the wrist and hand were normal. The axillary and supraclavicular lymph nodes were negative. Also, no mass could be found in the left thigh.

$\mathrm{X}$-ray of right humerus showed the complete osteolytic defect reaching from the middle $1 / 3$ to the epicondyle of the humerus, and a "moth-eaten" appearance could be seen proximally (Fig. 1). MRI showed the local cortical defect of right humerus and the mass of soft tissue of irregular and uneven density. Technetium bone scanning showed the radiation aggregation in the right upper arm. The thoracic X-ray, abdomen ultrasound and left thigh MRI proved negative.

The en bloc resection and prosthesis implantation of 
Table 1. Enneking functional outcome score

\begin{tabular}{|c|c|c|c|c|c|c|}
\hline Score & Pain & Function & $\begin{array}{l}\text { Emotional } \\
\text { acceptance }\end{array}$ & Hand positioning & Manual dexterity & Lifting ability \\
\hline 5 & $\begin{array}{l}\text { no pain in arm, no } \\
\text { pain medications }\end{array}$ & $\begin{array}{l}\text { not restricted in } \\
\text { daily activities, not } \\
\text { disabled }\end{array}$ & $\begin{array}{l}\text { enthusiastic about } \\
\text { surgery, would } \\
\text { recommend it to } \\
\text { others }\end{array}$ & $\begin{array}{l}\text { can lift arm over head } \\
\text { without difficulty }\end{array}$ & $\begin{array}{l}\text { no limitations in } \\
\text { manual dexterity } \\
\text { (i.e., button shirt, } \\
\text { write, etc.) }\end{array}$ & $\begin{array}{l}\text { can lift as much } \\
\text { weight as before } \\
\text { surgery }\end{array}$ \\
\hline 4 & $\begin{array}{l}\text { occasional } \\
\text { discomfort in arm, no } \\
\text { pain medications }\end{array}$ & $\begin{array}{l}\text { occasional } \\
\text { restrictions in } \\
\text { daily activities, not } \\
\text { disabled }\end{array}$ & $\begin{array}{l}\text { satisfied with surgery, } \\
\text { would recommend it } \\
\text { to others }\end{array}$ & $\begin{array}{l}\text { can lift arm over head } \\
\text { with some difficulty }\end{array}$ & $\begin{array}{l}\text { minimal limitations in } \\
\text { manual dexterity }\end{array}$ & $\begin{array}{l}\text { can lift slightly less } \\
\text { than before surgery }\end{array}$ \\
\hline 3 & $\begin{array}{l}\text { occasional pain in } \\
\text { arm, non-prescription } \\
\text { pain medications }\end{array}$ & $\begin{array}{l}\text { occasional } \\
\text { restrictions in daily } \\
\text { activities, minor } \\
\text { disability }\end{array}$ & $\begin{array}{l}\text { satisfied with } \\
\text { surgery, would not } \\
\text { recommend it to } \\
\text { others }\end{array}$ & $\begin{array}{l}\text { can lift arm up to } \\
\text { level of shoulder }\end{array}$ & $\begin{array}{l}\text { some loss of fine } \\
\text { movements and/or } \\
\text { sensation, limited } \\
\text { daily activity }\end{array}$ & $\begin{array}{l}\text { can only lift a greatly } \\
\text { reduced load than } \\
\text { before surgery }\end{array}$ \\
\hline 2 & $\begin{array}{l}\text { often pain in arm, } \\
\text { non-prescription } \\
\text { pain medications }\end{array}$ & $\begin{array}{l}\text { daily occupational } \\
\text { restrictions, minor } \\
\text { disability }\end{array}$ & $\begin{array}{l}\text { not fully satisfied } \\
\text { with surgery, would } \\
\text { still try it again }\end{array}$ & $\begin{array}{l}\text { have difficulty lifting } \\
\text { arm up to level of } \\
\text { shoulder }\end{array}$ & $\begin{array}{l}\text { significant loss of fine } \\
\text { movements and/or } \\
\text { sensation, inhibited } \\
\text { from daily activity }\end{array}$ & $\begin{array}{l}\text { can only lift arm } \\
\text { without any weight }\end{array}$ \\
\hline 1 & $\begin{array}{l}\text { occasional pain in } \\
\text { arm, prescription } \\
\text { pain medications }\end{array}$ & $\begin{array}{l}\text { some occupational } \\
\text { restrictions, major } \\
\text { disability }\end{array}$ & $\begin{array}{l}\text { accept surgery, } \\
\text { would repeat it } \\
\text { reluctantly }\end{array}$ & $\begin{array}{l}\text { cannot lift arm } \\
\text { forward above level } \\
\text { of waist }\end{array}$ & $\begin{array}{l}\text { difficulty with basic } \\
\text { dexterity such as } \\
\text { pinching and/or } \\
\text { major loss of } \\
\text { sensation }\end{array}$ & $\begin{array}{l}\text { can only use arm to } \\
\text { help other arm in } \\
\text { activities }\end{array}$ \\
\hline 0 & $\begin{array}{l}\text { disabling pain in arm, } \\
\text { daily prescription } \\
\text { pain medications }\end{array}$ & $\begin{array}{l}\text { total occupational } \\
\text { restriction, } \\
\text { completely disabled }\end{array}$ & $\begin{array}{l}\text { dislike surgery, would } \\
\text { not repeat }\end{array}$ & cannot move arm & $\begin{array}{l}\text { cannot grasp with } \\
\text { hand and/or it is } \\
\text { completely numb }\end{array}$ & $\begin{array}{l}\text { cannot even use arm } \\
\text { to help other arm }\end{array}$ \\
\hline
\end{tabular}

Table 2. Patient characteristics and outcomes

\begin{tabular}{|c|c|c|c|c|c|c|c|c|}
\hline $\begin{array}{c}\text { Patient } \\
\text { no. }\end{array}$ & $\begin{array}{l}\text { Sex/age } \\
\text { (years) }\end{array}$ & Involved site & Tumor stage & $\begin{array}{c}\text { Postoperative } \\
\text { chemotherapy } \\
\text { cycles }\end{array}$ & $\begin{array}{l}\text { Follow-up } \\
\text { (months) }\end{array}$ & Complications & Survival & $\begin{array}{l}\text { Functional result } \\
\text { (6 months after } \\
\text { the operation) }\end{array}$ \\
\hline 1 & $M / 30$ & proximal & $\| A$ & 6 & 24 & $\begin{array}{l}\text { pulmonary } \\
\text { metastases }\end{array}$ & no & excellent \\
\hline 2 & $M / 66$ & distal & III & 4 & 20 & local recurrence & no & fair \\
\hline 3 & F/39 & proximal & $\| B$ & 3 & 56 & no & yes & excellent \\
\hline 4 & $F / 44$ & mid shaft & $\| B$ & 6 & 12 & $\begin{array}{l}\text { pulmonary } \\
\text { metastases }\end{array}$ & no & poor \\
\hline 5 & $M / 56$ & proximal & $\| A$ & 2 & 32 & $\begin{array}{l}\text { pulmonary } \\
\text { metastases }\end{array}$ & no & good \\
\hline 6 & $M / 51$ & mid shaft & $\| \mathrm{B}$ & 3 & 6 & no & yes & fair \\
\hline 7 & $F / 56$ & mid shaft & III & 6 & 36 & no & yes & fair \\
\hline 8 & $F / 71$ & proximal & $\| B$ & 3 & 44 & no & yes & excellent \\
\hline 9 & $M / 48$ & distal & $\| B$ & 4 & 16 & $\begin{array}{l}\text { pulmonary } \\
\text { metastases }\end{array}$ & no & good \\
\hline 10 & $F / 46$ & proximal & $\| A$ & 4 & 20 & no & yes & fair \\
\hline 11 & $F / 67$ & proximal & $\| \mathrm{B}$ & 3 & 18 & $\begin{array}{l}\text { pulmonary } \\
\text { metastases }\end{array}$ & no & good \\
\hline 12 & $M / 59$ & distal & $\| A$ & 2 & 30 & no & yes & good \\
\hline 13 & F/46 & proximal & $\| B$ & 6 & 53 & no & yes & excellent \\
\hline 14 & $M / 62$ & mid shaft & III & 4 & 26 & $\begin{array}{l}\text { pulmonary } \\
\text { metastases }\end{array}$ & no & fair \\
\hline 15 & $M / 52$ & proximal & $\| \mathrm{A}$ & 4 & 28 & no & yes & fair \\
\hline
\end{tabular}


Fig. 1. X-ray showing the complete osteolytic defect reaching from the middle $1 / 3$ of the shaft to the epicondyle of the humerus

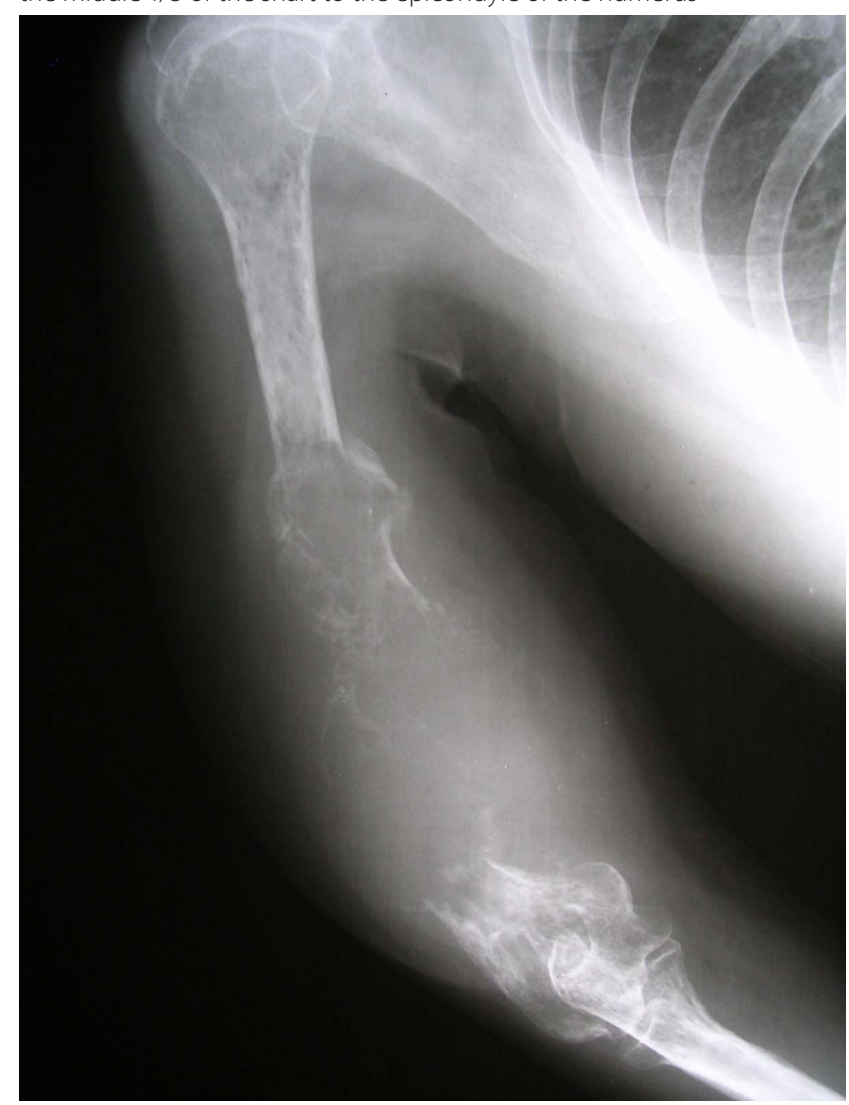

Fig. 2. The whole humerus replacement. The rotator cuff, the insertions of deltoid muscle and origins of forearm extensor and flexor muscles were reconstructed by using Gore-Tex aortic grafts

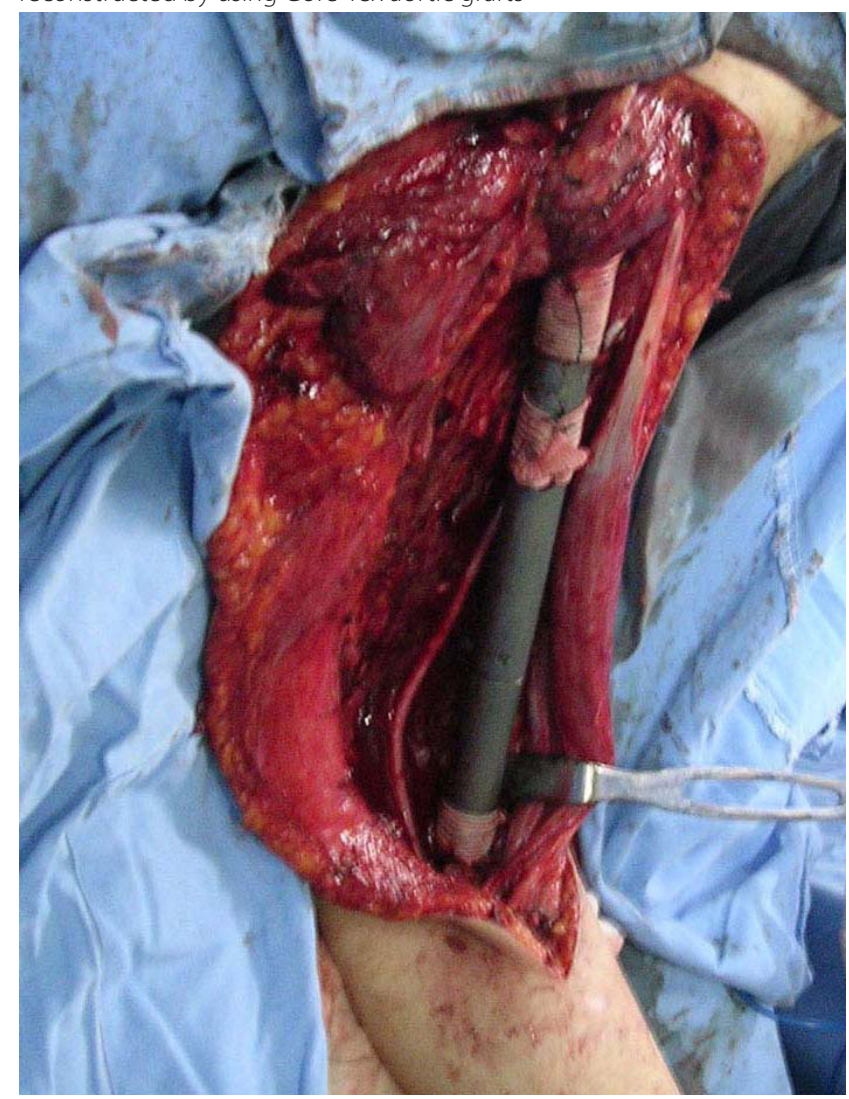

the whole humerus were performed. 1) En bloc resection of the humerus: The superior shoulder approach of James E, Thompson, Henry was used, and the anteromedial approach to the middle and distal segment of the upper arm was performed. The incision reached 5 $\mathrm{cm}$ distally below the elbow transverse line of the forearm. The shoulder joint and the whole humerus were exposed, and en bloc resection was performed through the approach. 2) Prosthesis implantation: The rotator cuff, the insertion of the deltoid muscle and the origins of the forearm extensor and flexor muscles were reconstructed using Gore-Tex aortic grafts. The distal end of the prosthesis was inserted into the proximal ulna (Fig. 2 and 3). After the operation, the shoulder joint was fixed on the abduction brace with the position of 80 degree abduction and 30 degree anteflexion and internal rotation.

The tumor was localized in the distal $2 / 3$ of the humerus in macroscopic findings. The cortex of the humerus was destroyed with a well-circumscribed border and the expansile mass was pseudo-encapsulated. The crosssection of the resected tumor appeared pale and fleshy with zones of hemorrhage, myxoid changes and necrosis (Fig. 4). In histological findings, a storiform growth pattern of tumor cells, nuclear pleomorphism and bizarre tumor giant cells admixed with spindle cells and stromal chronic inflammatory cells were found. For immunohistochemistry, the sections showed Vim(+), Lysozyme(+), Mac387 \& CD68(+), DES(-), S-100(-), MyoD1(-).

Postoperatively, the stitches were removed after 3 weeks and the abduction brace was discarded after 4 weeks. The patient received chemotherapy of doxorubicin and cisplatin for 6 cycles. The 36-month follow-up revealed no evidence of recurrence at the left arm and the right thigh. There were no metastases in the lungs. The function of the elbow, wrist and interphalangeal joints was satisfactory, but the abduction range of the shoulder joint was only 10 degrees.

\section{Discussion}

It was O'Brien and Stout who first recognized MFH as a histologically distinctive type of sarcoma in $1964 .{ }^{5}$ Since the clinicopathologic features of this tumor was defined, MFH has become the most common type of soft tissue sarcoma diagnosed in most cancer centers. The former MFH classification showed a broad range of histological appearances and consisted of 5 subtypes: storiform, pleomorphic, myxoid, giant cell and inflammatory. The 2002 WHO classification recognizes the presence of an undifferentiated, unclassifiable category of pleomorphic sarcoma and defines undifferentiated pleomorphic sarcoma as a group of pleomorphic sarcomas in which any attempt to disclose their line of differentiation has failed. ${ }^{6,7}$ It has to be emphasized that this is a diagnosis of exclusion following thorough sampling and judicious use of ancillary 
Fig. 3. X-ray showing the prosthesis

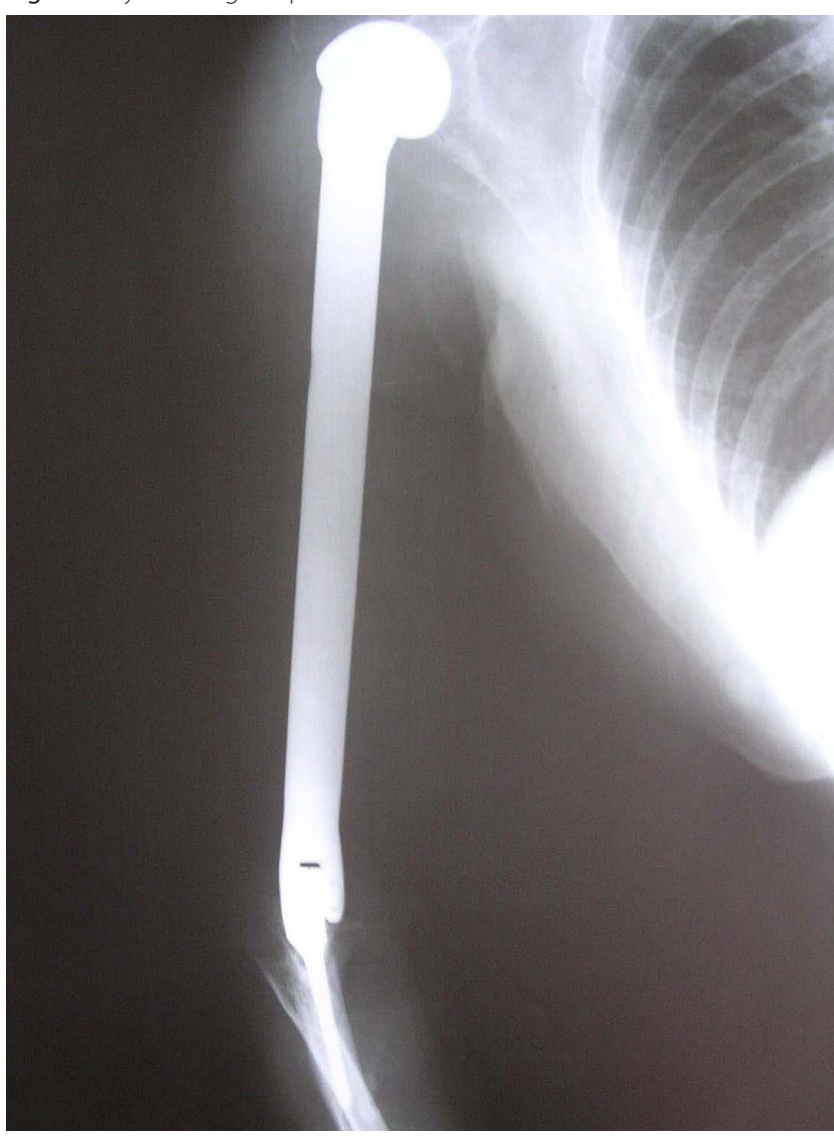

Fig. 2. Cross-section of the resected tumor showing a pale and fleshy appearance with zones of hemorrhage, myxoid changes and necrosis

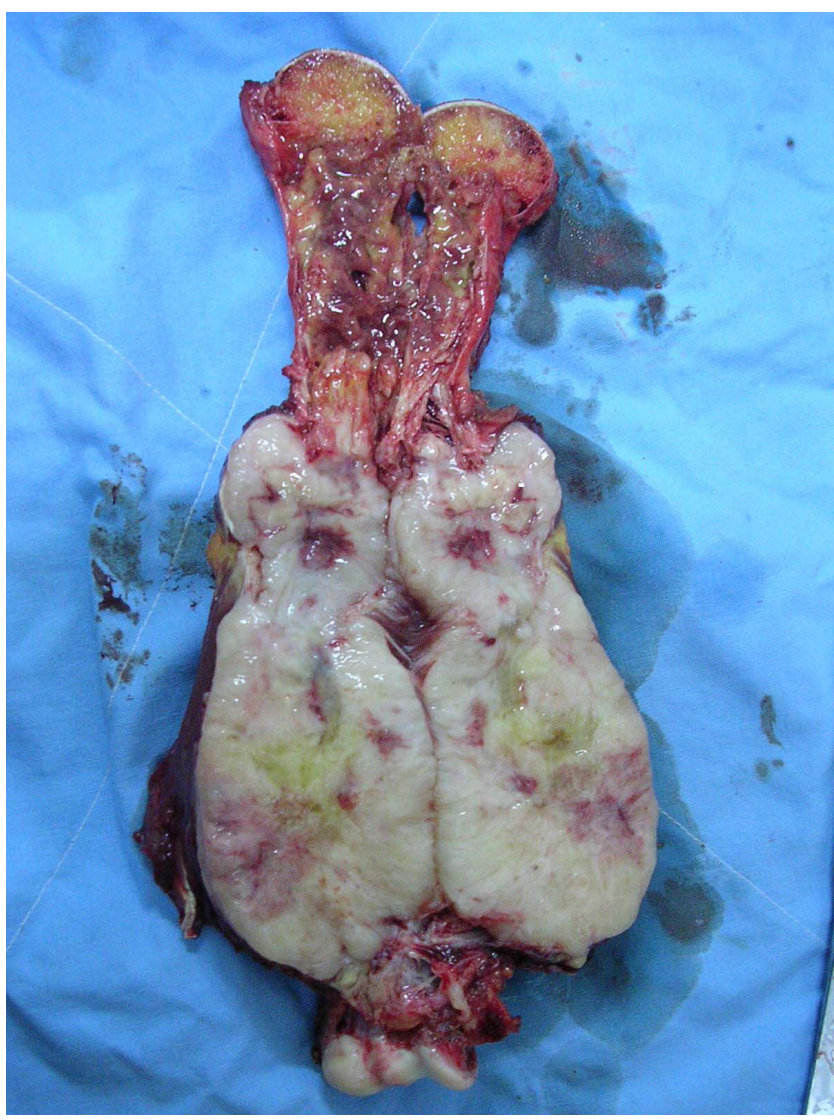

techniques. Most of those cases in the past have contributed to the category of storiform and pleomorphic MFH. ${ }^{8}$

The principles of osseous MFH treatment are somewhat like those for osteosarcoma. Resection or amputation is the mainstay of therapy. Limb salvage surgery is the treatment of choice for $70-85 \%$ of all malignant bone and soft tissue sarcomas in the limb. ${ }^{9}$ The decision to undergo amputation or limb salvage surgery is based on the tumor location, the tumor size, patient preferences, the possible complications and multiple reoperations, and the expected functional effect. Limb salvage surgery is generally the preferred treatment unless the functional prognosis is poor. It has been shown that the functional outcome of limb salvage surgery is superior to amputation. ${ }^{10}$ Five prognostic factors determine survival outcome: advanced patient age, presence of metastases at presentation, tumor size, tumor grade and tumor depth. ${ }^{11}$ It has been established that there has been no statistically significant survival difference found between amputation and limb salvage. ${ }^{12}$ Limb salvage surgery patients have better quality of life without compromising survival than those who have undergone amputation. ${ }^{13-15}$ Developments in adjuvant therapies, imaging diagnostics and surgical reconstructive techniques have made limb salvage surgery a preferred procedure for most primary sarcomas of the upper limbs with survival rates of $60-70 \% .16,17$ Today, major amputations are avoidable in most cases if the full potential of reconstructive possibilities is tapped. ${ }^{8}$

Osseous MFH is considered to be a tumor with a higher potential to recur locally. ${ }^{18}$ Unplanned biopsies or inadequate surgical procedures are a common problem. It is well accepted that positive histological margins are associated with increased rate of local recurrence. ${ }^{19,20}$ Also, it is widely accepted that a wide surgical resection margin is the most important prognostic factor in nearly every type of sarcoma, especially regarding the local recurrence rate. ${ }^{21}$ It has been described that recurrence occurred in $64 \%$ patients with inadequate margins, $19 \%$ with wide margins, and $6.5 \%$ with radical surgery. ${ }^{22}$ With the achievement of wide surgical margins, no significant difference exists in the recurrence rates between limb salvage and amputated patients. ${ }^{2}$

Negative surgical margins (R0) resection, the removal of the tumor in sano, is nonetheless the prerequisite and foremost oncologic parameter to save the patient from local recurrence. ${ }^{23}$ Tumor resection with negative margins (R0) is the goal of surgical treatment. Luetke stated that an amputation would be considered only when the tumor could not be excised with a safe margin. ${ }^{24}$ It is recommended that a wide margin could be achieved based on a pre-op MRI. MRI can display the tumor extent, compartment location and adjacent neurovascular structures, which allows the surgeon to know the expected margins and use of adjuvant therapies before the operation. Thus, surgical techniques should be started with careful preoperative planning with MRI to create a map of the desired plane of resection..$^{25}$ 
The technique most frequently employed for tumor removal is the so-called wide resection. This term means resection of a large amount of surrounding healthy tissue, with safety margins of $4-5 \mathrm{~cm}$ to the sides and $1-2 \mathrm{~cm}$ deep to the tumor. ${ }^{26,27}$ However, other studies suggest different safety margins. Robert recommended that the intention in all resected tumors was to gain clear margins with at least a centimeter of normal tissue around the tumor. ${ }^{11}$ Muramatsu considered that there was a need for 2-centimeter-wide margins for high-grade soft-tissue sarcomas and a need for 1-centimeter-wide margins for lowgrade bone tumors. If the width of the margin is over $1 \mathrm{~cm}$, major nerves are reserved. ${ }^{28}$ Some surgeons considered $2 \mathrm{~cm}$ above the tumor as an adequate margin for tumor resection. ${ }^{10,29}$ Vasileios recommended that final pathology should confirm a resection margin of at least $2.5 \mathrm{~cm}$ at all directions. ${ }^{30}$ Nevertheless, the Association of Directors of Anatomical and Surgical Pathology recommends that any margin macroscopically more than $5 \mathrm{~cm}$ is believed to be clear. ${ }^{31,32}$ In our patients, the lesion was removed as widely or radically as possible. The margin was at least $7 \mathrm{~cm}$ above or below the limit of increased activity of the bone scan. The dissection was done subfascially, and all the muscles in the compartment were resected with the tumor. At the level of the bone osteotomy, the muscles were severed.

We know that preserving critical neurovascular and musculoskeletal structures will allow the patient to maintain maximal limb function. ${ }^{11}$ Thus, a balance between resection and preservation is of great importance. In general, the main factor leading to amputation is the direct invasion of a major nerve while the vascular structure or bone involvement can often be reconstructed relatively easily after resection. ${ }^{33}$ If a single nerve must be removed in order to maintain sufficient margin, the decision depends heavily on the function of the nerve. The sacrifice of a major nerve will result in profound functional deficit after the limb salvage surgery. Functional deficit is often unacceptable to the patient. Evaluation of peripheral nerves, both clinically and with imaging, is very important in the evaluation of patients with limb soft tissue sarcomas. ${ }^{34}$ If an essential peripheral nerve is felt to be adjacent to a soft tissue sarcoma but not circumferentially surrounded, it can usually be salvaged by using the technique of epineural dissection. If, however, a critical nerve is circumferentially involved with a tumor, it must be sacrificed for the sake of local control. It is important to inform the patient that normal limb function is not possible. The issue of nerve involvement therefore becomes a critical factor in determining the possibility of limb salvage in borderline cases. ${ }^{34}$ In our study, we were well prepared for autologous nerve grafting if a nerve resection was done. We would use the sural nerve as a donor graft for peripheral nerve reconstruction. Luckily, only epineural dissection was needed as a means of preserving the major nerve when it was closely applied to the sarcoma in all cases. Therefore, because of nerve preservation, the influence on limb function was relatively small. Acceptable functional results were relatively easy to obtain.

In patients with a humerus malignant tumor, it is frequently likely to perform curative resection which spares the limb. However, reconstruction including autogenous grafts, allografts and prostheses remains a problem. It has been reported that prosthetic reconstruction has many advantages. Reconstruction with prosthesis offers immediate distal fixation and enables earlier chemotherapy after surgery. It is usually the least time-consuming option available. The prosthesis offers a constant pivot for hand and elbow function and limits pain from traction on the neurovascular bundle. ${ }^{35}$ The modular prostheses could regain the length of resected bone easily. Moreover, with the improvement of the materials and design, modern prostheses achieve the primary aim of providing long-term function for some patients with relatively low physical demands. ${ }^{36}$ Thus, the objectives of limb reconstruction after oncologic resection are achieved, including providing stability, optimizing the aesthetic outcome and preservation of functional capability with early return to function.

An important factor in the selection method for patients with limited life expectancy is a low rate of complications. With fewer complications and failures, prosthetic reconstruction surgery for metastatic bone disease may be preferable. But oncological reconstruction with the prostheses may appear to have higher complication rates compared with standard total joint arthroplasty due to the extensive nature of the operation, extensive tissue loss and the compromising effects of associated radiotherapy and chemotherapy. The most common complications in prosthetic reconstruction surgery are postoperative infection, prosthetic loosening, periprosthetic fractures and dislocation. The published literature reports a low rate of infection in patients undergoing proximal humerus replacement. Mayilvahanan reported an infection rate of $3.5 \% .{ }^{37}$ In our series, probably because of the limited number of patients, none of the aforementioned complications occurred. We knew that these patients might be unable to undergo revision surgery due to poor general health with progressive disease. More careful management was done compared with standard prosthesis replacement.

Self-respect, body image, impacts on education and employment opportunities are other important issues which should also be examined in patients who undergo either limb salvage surgery or amputation. ${ }^{13}$ The amputation of the upper arm would probably destroy the mental strength of the patient completely. For that reason, the preservation of the upper arm might be more emotionally acceptable than amputation, and the optimal method was en bloc resection and prosthesis implantation. It offered good stability, no pain mobility and overall satisfactory functional outcome in our patients.

Our study is subject to a number of limitations. Firstly, it includes only a small number of patients and lacks a control group. Secondly, our series of tumors was not 
homogeneous with respect to tumor location within the humerus, the stage and the adjuvant treatment. Thirdly, different procedures for soft tissue reconstruction were used, according to the specific situation. Fourthly, the follow-up period was too short in some patients to draw long-term conclusions regarding function and survival of the reconstruction.

\section{Conclusion}

For patients with humerus MFH, limb salvage procedures with chemotherapy is a practical treatment choice. The therapy not only improves quality of life but also offers a serviceable limb.

Reports of humerus MFH management are limited and contain only a small number of samples. Multicenter studies are needed to acquire statistically significant data that will be of great help for this patient population.

\section{References}

1. Schajowicz F. Tumours and tumour like lesions of bones and joints. New York, NY: Springer; 1994:427-438.

2. Natarajan MV, Mohanlal P, Bose JC. Limb salvage surgery complimented by customised mega prostheses for malignant fibrous histiocytomas of bone. J Orthop Surg (Hong Kong). 2007;15(3):352-356.

3. Enneking WF. A system of staging musculoskeletal neoplasms. Instr Course Lect. 1988;37:3-10.

4. Enneking WF, Dunham W, Gebhardt MC, Malawar M, Pritchard DJ. A system for the functional evaluation of reconstructive procedures after surgical treatment of tumors of the musculoskeletal system. Clin Orthop Relat Res. 1993;(286):241-246.

5. O'Brien JE, Stout AP. Malignant fibrous xanthomas. Cancer 1964;17:1445-1455.

6. Fletcher CDM, Unni KK, Mertens F. World health organization classification of tumours. Pathology and genetics of tumours of soft tissue and bone. Lyon, France: IARC Press; 2002;227-232.

7. Nascimento AF, Raut CP. Diagnosis and management of pleomorphic sarcomas (so-called "MFH") in adults. J Surg Oncol. 2008;97(4):330-339.

8. Lehnhardt M, Daigeler A, Homann HH, et al. MFH revisited: Outcome after surgical treatment of undifferentiated pleomorphic or not otherwise specified (NOS) sarcomas of the extremities - an analysis of 140 patients. Langenbecks Arch Surg. 2009;394(2):313-320.

9. Kolk S, Cox K, Weerdesteyn V, et al. Can orthopedic oncologists predict functional outcome in patients with sarcoma after limb salvage surgery in the lower limb? A nationwide study. Sarcoma. 2014:2014:436598.

10. Aksnes $\mathrm{LH}$, Bauer HC, et al. Limb-sparing surgery preserves more function than amputation: A Scandinavian sarcoma group study of 118 patients. J Bone Joint Surg Br. 2008;90(6):786-794.

11. Bains R, Magdum A, Bhat W, Roy A, Platt A, Stanley P. Soft tissue sarcoma - A review of presentation, management and outcomes in 110 patients. Surgeon. 2014 Sep 23. [Epub ahead of print].

12. Rosenberg SA, Tepper J, Glatstein E, et al. The treatment of softtissue sarcomas of the extremities: Prospective randomized evaluations of (1) limb-sparing surgery plus radiation therapy compared with amputation and (2) the role of adjuvant chemotherapy. Ann Surg. 1982;196(3):305-315.

13. Mei J, Zhu XZ, Wang ZY, Cai XS. Functional outcomes and quality of life in patients with osteosarcoma treated with amputation versus limb-salvage surgery: A systematic review and meta-analysis. Arch Orthop Trauma Surg. 2014;134(11):1507-1516.

14. Eiser C. Assessment of health-related quality of life after bone cancer in young people: Easier said than done. Eur $J$ Cancer. 2009;45(10):1744-1747.
15. Barr RD, Wunder JS. Bone and soft tissue sarcomas are often curable - but at what cost?: A call to arms (and legs). Cancer. 2009;115(18):4046-4054.

16. Tobias K, Gillis T. Rehabilitation of the sarcoma patient-enhancing the recovery and functioning of patients undergoing management for extremity soft tissue sarcomas. J Surg Oncol. 2015;111(5): 615-621.

17. Shehadeh A, El Dahleh M, Salem A, et al. Standardization of rehabilitation after limb salvage surgery for sarcomas improves patients' outcome. Hematol Oncol Stem Cell Ther. 2013;6(3-4):105-111.

18. Al-Absi E, Farrokhyar F, Sharma R, et al. A systematic review and meta-analysis of oncologic outcomes of pre- versus postoperative radiation in localized resectable soft-tissue sarcoma. Ann Surg Oncol. 2010;17(5):1367-1374.

19. Gibbs JF, Huang PP, Lee RJ, et al. Malignant fibrous histiocytoma: an institutional review. Cancer Invest. 2001;19(1):23-27.

20. Zagars GK, Ballo MT, Pisters PW, et al. Prognostic factors for patients with localized soft-tissue sarcoma treated with conservation surgery and radiation therapy: An analysis of 1225 patients. Cancer. 2003;97(10):2530-2543.

21. Weitz J, Antonescu CR, Brennan MF. Localized extremity soft tissue sarcoma: Improved knowledge with unchanged survival over time. J Clin Oncol. 2003;21(14):2719-2725.

22. Capanna R, Bertoni F, Bacchini P, Bacci G, Guerra A, Campanacci M. Malignant fibrous histiocytoma of bone. The experience at the Rizzoli Institute: Report of 90 cases. Cancer. 1984;54(1):177-187.

23. Hollier LH. Extremity-saving surgery and reconstruction: From microsurgery reconstruction to transplantation. Semin Plast Surg. 2010;24(1):3.

24. Luetke A, Meyers PA, Lewis I, Juergens H. Osteosarcoma treatment - where do we stand?: A state of the art review. Cancer Treat Rev. 2014;40(4):523-532.

25. Nystrom LM, Reimer NB, Reith JD, et al. Multidisciplinary management of soft tissue sarcoma. Scientific World J. 2013;2013:852462.

26. Enneking WF, Spanier SS, Goodman MA. A system for the surgical staging of musculoskeletal sarcoma. Clin Orthop Relat Res. 1980;(153):106-120.

27. Bannasch H, Eisenhardt SU, Grosu AL, Heinz J, Momeni A, Stark GB. The diagnosis and treatment of soft tissue sarcomas of the limbs. Dtsch Arztebl Int. 2011;108(3):32-38.

28. Muramatsu K, Ihara K, Yoshida K, Tominaga Y, Hashimoto T, Taguchi T. Musculoskeletal sarcomas in the forearm and hand: Standard treatment and microsurgical reconstruction for limb salvage. Anticancer Res. 2013;33(10):4175-4182.

29. Ayerza MA, Farfalli GL, Aponte-Tinao L, Muscolo DL. Does increased rate of limb-sparing surgery affect survival in osteosarcoma? Clin Orthop Relat Res. 2010;468(11):2854-2859.

30. Vasileios KA, Eward WC, Brigman BE. Surgical treatment and prognosis in patients with high-grade soft tissue malignant fibrous histiocytoma of the extremities. Arch Orthop Trauma Surg. 2012;132(7):955-961.

31. Recommendations for the reporting of soft tissue sarcoma. Association of Directors of Anatomic and Surgical Pathology. Virchows Arch. 1999;434(3):187-191.

32. Kandel R, Coakley N, Werier J, et al. Surgical margins and handling of soft-tissue sarcoma in extremities: A clinical practice guideline. Curr Oncol. 2013;20(3):e247-254.

33. Chao AH, Mayerson JL, Chandawarkar R, Scharschmidt TJ. Surgical management of soft tissue sarcomas: Extremity sarcomas. J Surg Oncol. 2015;111(5):540-545.

34. Clarkson PW, Griffin AM, Catton CN, et al. Epineural dissection is safe technique that facilitates limb salvage surgery. Clin Orthop Relat Res. 2005:438:92-96.

35. Wada T, Usui M, Isu K, Yamawakii S, Ishii S. Reconstruction and limb salvage after resection for malignant bone tumour of the proximal humerus: A sling procedure using a free vascularised fibular graft. J Bone Joint Surg Br. 1999;81(5):808-813.

36. Qadir I, Umer M, Baloch N. Functional outcome of limb salvage surgery with mega-endoprosthetic reconstruction for bone tumors. Arch Orthop Trauma Surg. 2012;132(9):1227-1232. doi: 10.1007/ s00402-012-1542-3.

37. Mayilvahanan N, Paraskumar M, Sivaseelam A, Natarajan S. Custom mega-prosthetic replacement for proximal humeral tumours. Int Orthop. 2006;30(3):158-162. 